\title{
The Effect of Leadership Style, Culture and Organizational Commitment to Employee Performance
}

\author{
Didin Achmad Jaenudin ${ }^{1}$, Azmi Fitriati ${ }^{2}$, Herni Justiana Astuti ${ }^{3}$ \\ Magister Management, Universitas Muhammadiyah Purwokerto, Purwokerto ${ }^{123}$
}

\begin{abstract}
The purpose of this paper is to examine the influence of leadership style, culture and organizational commitment on employee performance. The sample is employees at PT. Yodya Karya (Persero), Indonesia. Leadership styles are measured using transformational and transaction leadership indicators. Organizational culture is measured by innovation and risk-taking, attention to detail, outcome orientation, a people orientation, team orientation, aggressiveness, and stability. The organizational commitments have three dimensions: affective, continuance, and normative commitments. Employee performance is measured through task, adaptive, and contextual performance indicators. The analysis used is Structural Equation Modelling (SEM) based component or variance by using Partial Least Square (PLS). The conclusion is leadership style, culture and organizational commitment influence employee performance. Effective leadership styles can inspire and motivate employees to work hard to achieve the goals and successes of individuals and organizations. Organizational culture can affect employee behavior and attitudes. Organizational culture can serve as a powerful tool for implementing innovative ideas, influencing employee behavior, and improving performance. Employee commitment to the organization can also improve their performance.
\end{abstract}

Keywords: Leadership style, Organizational culture, Organizational commitment, Employee Performance

\section{Introduction}

Each company seeks to have a competitive advantage to survive in a constantly changing market environment. The company will strive to develop the quality of human resources to optimize employees ' performance as a source of strategic excellence [1]. According to [2] Employee performance and productivity can improve organizational performance [3][4]. The changing and rapid movements in business, organizational performance requires innovation and the development of employee role performance [5].

[6] defines performance as the level of achievement of activities or policies in realizing organizational goals, objectives, vision, and mission. Employee performance is the result of work in quality and quantity achieved by employees in carrying out tasks under the responsibilities given [7]. [8] Define the performance of its employees as a working achievement of individual performance functions according to job standards. Some research finds that employee performance is influenced by leadership styles, cultures, and organizational commitments.

Leadership style is the ability of a leader in managing existing resources within the company. Effective leadership styles can improve employee performance. Performance-oriented 
leadership styles are indispensable for dealing with highly competitive business competition and fast changes.

Another factor affecting employee performance is organizational culture. Organizational culture is defined as values, principles, traditions, and attitudes that influence the way members of an organization behave in it [9], [10]. Organizational culture controls how employees interact within and outside the organization. Organizational norms and values that become organizational culture have a strong effect on all people who are bound to the organization [11]. Organizational culture can serve as a powerful tool for implementing innovative ideas, influencing employee behavior, and improving performance.

Organizational commitment is also a factor that affects employee performance. According to [9] organizational commitment is the condition of an employee that is aligned with the goals of the organization. They also have a desire to maintain membership in the organization. Employees who are highly committed to the organization have a high level of attendance and a long working period. High commitment also tends to work harder and show high achievements [12].

\section{Literature Review}

\subsection{Employee Performance}

Each company seeks to have a competitive advantage to survive in a constantly changing market environment. The company will strive to develop the quality of human resources to optimize employees ' performance as a source of strategic excellence [1]. According to [2] Employee performance and productivity can improve organizational performance [3][4]. The changing and rapid movements in business, organizational performance requires innovation and the development of employee role performance [5].

[6] defines performance as the level of achievement of activities or policies in realizing organizational goals, objectives, vision, and mission. Employee performance is the result of work in quality and quantity achieved by employees in carrying out tasks by the responsibilities given [7]. [8] Define the performance of its employees as a working achievement of individual performance functions according to job standards. Some research finds that employee performance is influenced by leadership styles, cultures, and organizational commitments.

Leadership style is the ability of a leader in managing existing resources within the company. Effective leadership styles can improve employee performance. Performance-oriented leadership styles are indispensable for dealing with highly competitive business competition and rapid changes.

\subsection{Leadership Style and Employee Performance}

Leadership is an interpersonal process that can affect the activity of individuals or groups to achieve goals through communication. [13] define leadership as the process of forming or influencing people to achieve organizational objectives. According to [14] Leadership is the process of influencing and motivating to encourage the participation of others in achieving goals.

[15] defined leadership as to how leaders communicate and relate to people, motivate and train subordinates and give direction to their team to perform their duties. Influencing is the leader's process of communicating ideas and motivating employees to support and implement 
them through change [16]. Great leaders not only inspire employees to improve efficiency in achieving organizational objectives.

Leadership styles are how leadership functions are performed and how managers behave towards employees. Leadership style is the way a leader interacts with subordinates. That style is the approach that is used to motivate subordinates. Leadership style is a combination of traits, characteristics, skills, and behavior of leaders when interacting with subordinates [17].

Leadership styles are chosen and adapted to organizations, situations, groups, and individuals. [18] confirm that force and leadership support will increase employee engagement. Leaders must adjust their style to suit the situation and condition of a particular group. There are many styles, features, and philosophy of Leadership [19][20][21][22][23]. According to [24], leadership styles include bureaucracy, laissez-faire, charismatic, democratic, transactional, and transformational. [25] Classifying leadership styles only include transactional and transformational.

According to [26], [27], [28], [29] Leadership style has an effect on employee performance. Leadership styles will influence the ability and motivation of employees to achieve organizational goals and objectives [30]. [31] found that leader behavior in carrying out tasks affected employee performance. Furthermore, [31] states that the behavior of leaders in carrying out their functions is the key to achieving organizational performance. [32] found a positive influence of leadership style on employee performance. Leadership plays an important role to ensure improvement in individual and organizational performance.

[33] [34] explains that performance as achievement, execution, execution of the work, or activities undertaken is heavily influenced by the leadership style. The effectiveness of a group of people depends heavily on leadership qualities. Effective leader behavior can facilitate the achievement of follower desires, which can improve performance [35] [36]. [37] suggest that effective leadership styles will inspire and motivate employees to work hard to achieve the goals and successes of individuals and organizations.

[38] that leadership role and leadership styles are crucial in managing employee retention. Leadership styles can motivate employees, which in turn leads to an increase in performance levels and the tendency of retention of employees in the organization [39]. [40], and [41] found a positive relationship between transformational leadership and employee performance at various levels. Other studies found that transactional leadership can improve job satisfaction and employee performance.

\subsection{Organizational Culture and Employee Commitment}

Organizational culture is a system of values and beliefs that are embraced together, organizational structures, and surveillance systems to produce behavioral norms in an organization [42]. Organizational culture is a way of thinking, feeling, and reacting based on certain patterns in the organization [43]. Organizational culture is the norms and values that direct the behavior of the member of the organization in which each member will behave by the culture that is acceptable to be accepted by the environment [10].

Organizational culture is also defined as values, principles, traditions, and attitudes that affect the way the organization members behave [9]. [44] Define the organizational culture as a collection of values and norms that apply in an organization. According to [45], organizational culture is a rule of conduct, guiding policies on how to interact among members of the organization. Organizational culture controls how employees interact inside and outside your organization. The norms and values of organizations that become organizational cultures have a strong effect on all those who are bound by the organization [11]. 
According to [46], [47] Organizational culture is categorized into four categories: clans, Adhokrasi, markets, and hierarchies. As for [48] Classify organizational culture into dimensions: leadership ability to take risks, tolerance, outcome-oriented, institutional collectivism, and a positive working environment. Other than [49] classifies organizational culture into competitive, bureaucratic, and community dimensions. [50] Divide the organizational culture into a supportive, innovative, and bureaucratic culture. [19] states the organizational culture has dimensions: (1) value, ethics and moral identity, and creative; (2) rituals; (3) heroes; and (4) symbols.

[51] use collectivism and individualism as the cultural dimension of the organization. Furthermore, [9] use seven dimensions of organizational culture, namely: a) innovation and risktaking, employees are encouraged to be innovative and risk-takers; b) attention to detail, employees are expected to demonstrate accuracy, analysis, and attention to detail; c) outcome orientation, management focuses more on the outcome of the technique and the process of achieving the result; d) people orientation, which management decisions consider the impact of employee outcomes; e) team orientation, work activities organized by a team; f) aggressiveness, employees are encouraged to be aggressive and competitive; and g) stability, organizational activities emphasize on the maintenance of the status quo.

[52], [53] found that organizational culture is a key factor in achieving employee performance success. [54] Examine the influence of organizational cultural dimensions such as innovation, communication, environment, humanistic workplace, commitment, system, and orientation of outcomes on employee performance. Organizational culture affects employee behavior and attitudes. The culture that awakens depends on the views and characteristics of employees working in the organization. Organizational culture can serves as a powerful tool to implement innovative ideas, influence employee behavior, and improve performance.

\subsection{Organizational Commitment and Employee Performance}

According to [9], organizational commitment is the state of an employee siding with the objectives of the organization and has the desire to maintain membership in the organization. [55] defines organizational commitment is a strong desire to align with organizational objectives and values, willingness to make many efforts on behalf of organizations and a strong desire to remain a member of the organization. According to [56], organizational commitment is the force that binds a person to action that is relevant to one or more target organizations.

Organizational commitment is a strong trust and acceptance of organizational objectives and values; Willingness to exert great effort on behalf of organizations; and a strong desire to keep working with the organization [57]. Organizational commitments include strong body confidence and acceptance of organizational objectives and values; Willingness to exert great effort on behalf of organizations; and a strong desire to keep working with the organization [58]. The organizational commitments refer to the level of adoption of organizational values in identifying problems to fulfill the employment responsibilities of members of the Organization [59]. [60], [58] stated that the form of commitment, among others, is the support of work ethic, career commitment, job involvement, and union commitment focusing on values, careers, and employment.

According to [61], organizational commitments have three dimensions: affective, continuance, and normative commitments. Affective commitment is an employee's psychological affective attachment to its work. [62], expressed the affective commitment as a rate at which individuals were psychologically related to the organization through feelings of loyalty, affection, and possess. [63] defines affective commitment as a love of organization. 
Continuance commitment is the level of commitment employees will survive or leave the organization due to rational considerations [61]. [64], expressed ongoing commitment as a feeling of love for the organization because employees considered the magnitude of the sacrifice if he left the organization. [63] also defined a continuing commitment as a feeling of love for the organization because the investments that employees felt both psychologically and economically more profitable than if they were out of the organization.

Normative commitment is defined as the obligation to persist in the work. This commitment causes employees to remain in the organization because they feel obligated to have beliefs about what is right and morality [61]. [64], suggested that normative commitments are a reflection of the feeling of an employee obliged to reside in the organization.

According to [65], High organizational commitments can improve employee performance. The strong belief in the value and objectives of the Organization, the willingness to make many efforts on behalf of the Organization and the strong desire to remain a member of the organization can motivate employees to work better [55] [66]. Employee achievement and performance is characterized by the skills, efforts, and nature of the working conditions [67]. Effective work results will be gained when employees have a strong commitment to organizational and psychological attachment with the organization [66] [68].

Organizational commitment is a willingness to give effort and loyalty to the organization [69]. This commitment can improve employee morale and behavior to work better and generate work performance [70]. Organizations need committed employees. Employees who commit to an organization tend to have high loyalty [71], became a good member of the organization [56] and did his work effectively [72][73].

Highly committed employees can do jobs that exceed management expectations [74]. Commitments are indispensable for improving performance, gaining competitiveness, and sustained profitability. Human resources with high commitment will increase the effectiveness of the organization. Employees are constantly motivated and engaged in organizational activities to achieve organizational objectives [75].

[76] state that employees are considered committed to the organization if they will continue their relationship with the Organization and devote many efforts to achieving the destination organization. Employees with a high level of organizational commitment lead to higher levels of performance and effectiveness at individual and organizational levels.

\section{Result And Discussion}

The research design uses a survey approach based on quantitative measurements. The type of data used is primary data. Data collection techniques using questionnaires. The population in this study is all employees of PT. Yodya Karya (Persero). Sampling using purposive sampling techniques.

The variables in this study are leadership style, organizational culture, organizational commitment, and employee performance. These variables are latent. The variable operational definitions are presented in table 1 .

Table 1. Operational Definition Variables

\begin{tabular}{|c|c|c|}
\hline Variables & Dimensions & Indicators \\
\hline $\begin{array}{l}\text { Leadership } \\
\text { style [25] }\end{array}$ & $\begin{array}{l}\text { Transformational } \\
\text { leadership }\end{array}$ & $\begin{array}{l}\text { Idealized influence } \\
\text { Inspirational motivation } \\
\text { Intellectual simulation }\end{array}$ \\
\hline
\end{tabular}




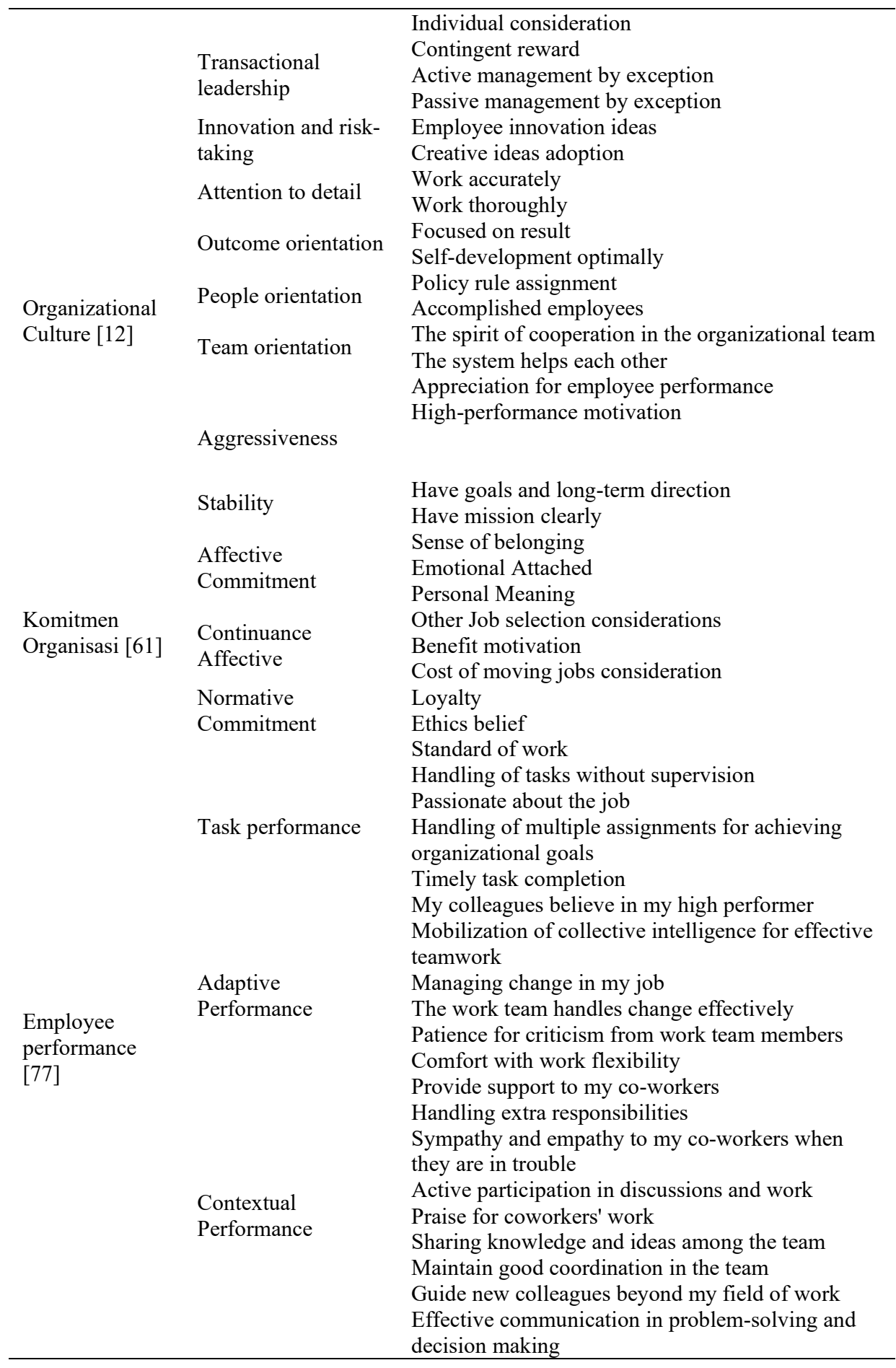


Data in this study was measured using an ordinal scale (rating scale). The ordinal scale is symmetrical and has the same distance between each category, can be treated like an interval scale [78]. The analytical tools used are Structural Equation Modelling (SEM) based component or variance using Partial Least Square (PLS). The analysis of PLS-SEM consists of the measurement model (outer model) and the structural model (inner model). The measurement models in this study used the first and second orders. The first order is a dimensional measurement model of the indicator. The second order is a model of latent variable measurement against its dimensions.

Model PLS-SEM evaluated through two stages, namely evaluation of model measurement and evaluation of the structural model. Evaluation of the measurement model was conducted to assess the reliability and validity of latent variable forming indicators. The evaluation is among other: (1) Validity of the indicator, using the criteria of significance factor loading [79]; (2) Reliability of the indicator, with the criteria of the R2 value not less than 0.5 [79]; (3) Validity of the indicator convergence per dimension, with the value criteria of AVE (Average Variance Extracted) more than 0.5 [78]; (4) Reliability of internal consistency of indicators per dimension; by using Composite Reliability (CR) value more than 0.7 [78]; and (5) The validity of discriminant indicators per dimension, using the criteria of the value of the Fornell-Lacker indicator of a dimension should be greater for that dimension than for other dimensions [78].

Evaluation of structural models according to [78] Among them is by (1) test the value of the coefficient of determination $\left(\mathrm{R}^{2}\right)$ indicates the accuracy size of the predictive model. $\mathrm{R}^{2}$ values range from 0 to 1 , the higher the value indicates the higher the accuracy value; (2) test path significance coefficient.

\section{Conclusion}

Employee performance is a working achievement as an individual performance standard in realizing organizational goals, objectives, vision, and mission. Such performance can be measured through indicators: task, adaptive, and contextual performance. Employee performance is influenced by several factors, among others: leadership style, culture, and organizational commitment.

Leadership is the process of influencing and motivating to encourage the participation of others in achieving goals. Leadership style is the way a leader interacts and motivating employees. There are many styles, features, and philosophy of leadership, such as transformational and transactional leadership. Leadership style support can increase employee engagement. Effective leadership style will inspire and motivate employees to work hard to achieve the goals and successes of individuals and organizations.

Organizational culture is a value, principle, tradition, and attitude that affects how members of the organization behave to be accepted by their environment. The cultural dimensions of the organization include innovation and risk-taking, attention to detail, outcome orientation, people orientation, team orientation, aggressiveness, and stability. Organizational culture can affect employee behavior and attitudes. Organizational culture can serves as a powerful tool to implement innovative ideas, influence employee behavior, and improve performance.

Organizational commitment is a strong desire to align with organizational objectives and values, willingness to make many efforts on behalf of organizations and a strong desire to remain a member of the organization. The organizational commitments have three dimensions: affective commitments, ongoing commitments, and normative commitments. Organizational 
commitments can improve employee performance. Strong belief in organizational values and objectives, willingness to make a lot of effort on behalf of the organization and the strong desire to remain a member of the organization can motivate employees to better work.

\section{References}

[1] Wright, P.M. and Snell, S.A. (2009), "Human resources, organizational resources, and capabilities", in Storey, J., Wright, P. and Ulrich, D. (Eds), The Routledge Companion to Strategic Human Resource Management, Routledge, London, pp. 345-356.

[2] Al Damoe, A. M., Yazam, M. and Ahmed, B. K. (2012). The mediating effect of HRM outcomes (employee retention) on the relationship between HRM practices and Organizational Performance. International Journal of Human Resource Studies. 2(1), 2162-2068

[3] Kalay, F. (2016). The impact of organizational justice on employee performance: a survey in Turkey and Turkish context. International Journal of Human Resource Studies. 6, 1-20

[4] Fu, W., and Deshpande, S.P. (2014), The impact of caring climate, job satisfaction, and organizational commitment on job performance of employees in a China's insurance company. Journal of Business Ethics, 124(2), 339-349

[5] Duarte, M.B. (2015), Organisational and professional commitments: The influence in nurses organisational citizenship behaviours. Tékhne, 13(1), 2-11

[6] Moeheriono (2010). Pengukuran Kinerja Berbasis Kompetensi. Bogor: Ghalia Indonesia

[7] Mangkunegara, A. P. (2006). Evaluasi Kinerja SDM. Bandung: PT. Refika Aditama

[8] Yozgat, U., Yurtkoru, S., Bilginoglu, E. (2013). Job stress and job performance among employees in the public sector in Istanbul: examining the moderating role of emotional intelligence. Social and Behavioral Sciences, 75, 518-524

[9] Robbins, S. and Judge, T.A. (2007). Organizational Behaviour. 12th edition. Upper Saddle River: New Jersey

[10] Luthan, F. (2011). Organization Behavior. An Evidence-Based Approach. 12th edition. McGrawHill

[11] Isa, M. F. M., Ugheoke, S. O., and Noor, W.S. W. M. (2016). The influence of organizational culture on employees' performance: evidence from Oman. Journal of Entrepreneurship and Business E-ISSN: 2289-8298.DOI:10.17687/JEB.0402.01

[12] Robbins, S.P. and Coulter, M. (2010). Management. Pearson Higher Education \& Professional Group

[13] Griffin, R. W. and Moorhead, G. (2009). Organizational Behavior: Managing People and Organizations. Ninth edition. South Western:USA

[14] Yukl, G., (2010). Leadership in organizations (7th ed.). Upper Saddle River, NJ: Pearson Education, Inc.

[15] Gharibvand, S., 2012. The Relationship between Malaysian Organizational Culture, Participative Leadership Style, and Employee Job Satisfaction among MalaysianEmployees from Semiconductor Industry. International Journal of $\quad$ Business and Social Science, 3(16), pp. 289298

[16] Lussier N. R. and Christopher, A.F. (2010). Leadership: Theory, application, \& skill development. 4th ed. University of Virginia's College at Wise. South-Western Cengage Learning

[17] Jeremy, M., Melinde, C., and Ciller, V. (2012). Perceived leadership style and employee participation in a manufacturing company in the democratic republic of Congo. African journal of business management, .6(15), 5389-98

[18] Ologbo C. A. and Saudah, S. (2012). Individual factors and work outcomes of employee engagement. Procedia - Social and Behavioral Sciences, 40, 498-508

[19] Hofstede, G. (1980). Culture's Consequences: International Differences in Work-Related Values, Sage, Beverly Hills, CA

[20] Javidan, M., House, R., Dorfman, P., Hanges, P., and Sully de Luque, M. (2006), Conceptualising and measuring cultures and their consequences: a comparative review of GLOBE's and Hofstede's approaches. Journal of International Business Studies, 37, 897-914 
[21] Jogulu, U. and Wood, G. (2006). The role of leadership theory in raising the profile of women in management. Equal Opportunities International. 25, 236-50.

[22] Jogulu, U. and Wood, G. (2007). Is transformational leadership always the answer? Engineering Management. 17.

[23] Jogulu, U. and Wood, G. (2008). A cross-cultural study into peer evaluations of women's leadership effectiveness. Leadership \& Organization Development Journal, 29, 600-16

[24] Rad, A. M. M., and Yarmohammadian, M. H. (2006). A study of relationship between managers' leadership style and employees' job satisfaction. Leadership in Health Services, 19(2), 11-28

[25] Rees, G. and French, R. (2013). Leading, managing, and developing people. 4 th ed. London: CIPD

[26] NawoseIng'ollan, D. and Roussel, J. (2017). Influence of leadership styles on employees' performance: a study of Turkana County, Kenya. International Journal of Business and Social Science. 8(7), 82-98

[27] Veliu, L., Manxhari, M., Demiri, V., and Jahaj, L. (2017). The influence of leadership styles on employee's performance. Vadyba / Journal of Management, 31(2), 59-69

[28] Otieno, B. B. A., Waiganjo, E. W., \& Njeru, A. (2015). Effect of employee engagement on organization performance in Kenya's horticultural sector. International Journal of Business Administration, 6(2)

[29] Gadot, E. (2006). Leadership style, organizational politics, and employees' performance An empirical examination of two competing models, Leadership style, 36(5), 661-683

[30] Menz, M. (2012). Functional top management team members: a review, synthesis, and research agenda. Journal of Management, 38(1), 45-80

[31] Wang, F. J., Chich-Jen, S., and Mei-Ling, T. (2010). Effect of leadership style on organizational performance as viewed from the human resource management strategy. African Journal of Business Management, 4(18), 3924-36

[32] Shahab, M. A. and Nisa, I. (2014). The influence of leadership and work attitudes toward job satisfaction and performance of employee. International Journal of Managerial Studies and Research (IJMSR), 2(5)

[33] Gul, S., Ahmad, B., Rehman, S.U., Shabir, N. and Razzaq, N. (2012). Leadership styles, turnover intentions and the mediating role of organisational commitment. Information and Knowledge Management, 2(7), 44-51

[34] Walumbwa, F. O., Mayer, D. M., Wang, P., Wang, H., Workman, K., and Christensen, A. L. (2011). Linking ethical leadership to employee performance: The rolës of leader-member exchange, self-efficacy, and organisational identification. Organizational Behaviour and Human Decision Processes, 115, 204-213

[35] Maritz, D. (1995). Leadership and mobilizing potential. Human Resource Management, 10(1), 8-16

[36] Ristow, A., Amos, T., Staude, G., (1999). Transformational leadership and organizational effectiveness in the administration of cricket in South Africa. South African Journal of Business Management 30 (1), 1-5

[37] Phillips, J. M. and Gully, S. M. (2012). Organizational behavior tools for success. Mason, SouthWestern Cengage learning

[38] Ng'ethe, J.M., Namasonge, G.S., and Mike, A.I. (2012). Influence of leadership styles on academic staff retention in public universities in Kenya. International Journal of Business and Social Science, 3 (21), 297-302

[39] Rochelle J. B. (2012). The effect of leadership style on employee satisfaction and performance of bank employees in Bangkok. 5(2). AU-GSB e-journal, 111-116

[40] Dvir, T.M., Eden, D., Avolio, B. J. \& Shamir, B. (2002). Impact of transformational leadership on follower development and performance: a field experiment. Academy of Management Journal, 45(5), 735-744

[41] Howell, J. M., Neufeld, D.J., and Avolio, B.J. (2005). Examining the relationship of leadership and physical distance with business unit performance. The Leadership Quarterly, 16, 273-285

[42] Kast, F. E. and Rosenzweig, J. E. (1985). Organization and Management; New York; McGraw-Hill Book Company 
[43] Tosi, H.L., Rizzo, J.R., and Caroll, S.J. (1990). Managing Organizational Behavior. New York: Harper Collins Publishers

[44] Hill, C.W.L. and Jones, G. 2009. Strategic Management Theory: An Integrated Approach. SouthWestern. Cengage Learning

[45] Alvesson, M. (2002). Understanding Organizational Culture. SAGE Publications

[46] Quinn, K. S. C., and Robert, E. (2011). Diagnosing and changing organizational culture: Based on the competing values framework. John Wiley \& Sons

[47] Tseng, S. M. (2010). The correlation between organizational culture and knowledge conversion on corporate performance. Journal of Knowledge Management, 14(2), 269-284

[48] Gu, V. C., Hoffman, J. J., Cao, Q., and Schniederjans, M. J. (2014). The effects of organizational culture and environmental pressures on IT project performance: A moderation perspective. International Journal of Project Management, 32(7), 1170-81

[49] Zehir, C., Ertosun, Ö. G., Zehir, S., and Müceldili, B. (2011). The effects of leadership styles and organizational culture over firm performance: Multi-National companies in İstanbul. ProcediaSocial and Behavioral Sciences, 24(1), 1460-74

[50] Yiing, L. H., and Ahmad, K. Z. B. (2009). The moderating effects of organizational culture on the relationships between leadership behaviour and organizational commitment and between organizational commitment and job satisfaction and performance. Leadership and Organization Development Journal, 30(1), 53-86

[51] Klehe, U. C., and Anderson, N. (2007). The moderating influence of personality and culture on social loafing in typical versus maximum performance situations. International Journal of Selection and Assessment, 15(2), 250-262

[52] Salehipour, A. and Ahmand, A. (2018). The impact of organizational culture and performance work system on employees' performance. International Business Research; 11(6), 199-212

[53] Durgadevi, R. and Vasantha, S. (2017). Organizational culture and its impact on employee performance (A study with reference to IT sector Chennai). Indian Journal of Public Health Research \& Development, 8(2)

[54] Sinha, A., \& Arora, B. (2012). Fit between organizational culture and business excellence: a case study of heavy electrical equipment plant, BHEL. Vikalpa: The Journal For Decision Makers, 37(3), $19-27$

[55] Azeem, S. M. (2010). Job satisfaction and organizational commitment among employees in the Sultanate of Oman. Psychology Journal, Vol. 1, 295-299

[56] Meyer, J.P., Stanley, D.J., Herscovitch, L., Topolnytsky, L. (2002), Affective, continuance, and normative commitment to the organization: A meta-analysis of antecedents, correlates, and consequences. Journal of Vocational Behavior, 61(1), 20-52

[57] Neubert, M.J. and Halbesleben, K. (2015). Called to commitment: An examination of relationships between spiritual calling, job satisfaction, and organizational commitment. Journal of Business Ethics. 132(4), 859-872

[58] Dajani, M. A. Z. 2015. The impact of employee engagement on job performance and organisational comitment in the Egyptian Banking Sector. Journal of Business and Management Sciences. 3, $138-147$

[59] Mohammed, F. and Eleswed, M. 2013. Job satisfaction and organizational commitment: a correlational study in Bahrain. International Journal of Business, Humanities and Technology, 3(5), 43-53

[60] Borghei, R., Gholamreza, J., Hasan, Z.M., Nasrin, D. (2010). An examination of the relationship between empowerment and organizational commitment. International Journal of Humans Sciences. Vol. 7, 1155-71

[61] Meyer, J.P., and Allen, N.J. (1991), A three-component conceptualization of organizational commitment. Human Resource Management Review, 1(1), 61-89

[62] Chang, E. (1999). Career commitment as a complex moderator of organization al commitment and turnover intention. Human Relations. 52(10), 1257-78 
[63] Somers, M. and Birnbaum, D. 2000. Exploring the relationship between commitment profiles and work attitudes, employee withdrawal, and job performance. Public Personnel Management. Vol. 29. 353-356

[64] Burr, R. and Girardi, A. (2002). Intellectual capital: more than interaction of competence commitment. Australian Journal of Management. Vol 27 Special Issue, 77-88

[65] Khan, M. R., Ziauddin, F. A., Ramay, M.I. 2010. The impacts of organizational commitment on employee job performance. European Journal of Social Sciences, 15(3)

[66] Al Zefeiti, S.M.B. and Mohamad, N.A. (2017). The influence of organizational commitment on Oman public employees' work performance. International Review of Management and Marketing, $7(2), 151-160$

[67] Ling, S.M. and Bhatti, M. A. (2014). Work stress and job performance in Malaysia academic sector: role of social support as moderator. British Journal of Economic, Management and Trade, Vol. 12, 1986-98

[68] Sharma, P. and Sinha, V. (2015). The influence of occupational rank on organizational commitment of faculty members. Management Journal, Vol. 20, 71-91

[69] Lapointe, E., and Vandenberghe, C. (2018). Examination of the relationships between servant leadership, organizational commitment, and voice and antisocial behaviors. Journal of Bus Ethics, 109, 301-307

[70] Jayaweera, T. (2015). Impact of work environmental factors on job performance, mediating role of work motivation: a study of hotel sector in England. International Journal of Bussines and Management, Vol. 10, 271-278

[71] Tett, R.P., Meyer, J.P., 1993. Job satisfaction, organizational commitment, turnover intention, and turnover: Path analyses based on meta-analytic findings. Personnel Psychology, 46: 259-293

[72] Cooper-Hakim, A., Viswesvaran, C., (2005). The construct of work commitment: Testing an integrative framework. Psychological Bulletin, 131: 241-259

[73] Riketta, M., (2002). Attitudinal organizational commitment and job performance: A meta-analysis. Journal of Organizational Behavior, 23: 257-266

[74] Bragg, T., (2002). Improve employee commitment. Industrial Management, 7(8): 18-20

[75] Boxall, P., and Macky, K., (2009). Research and theory on high-performance work systems: progressing the high- involvement stream. Human Resource Management Journal, 19: 3-23

[76] Sharma, J.P., Bajpai, N., 2010. Organizational commitment and its impact on job satisfaction of employees: A comparative study in public and private sector in India. International Bulletin of Business Administration, 9: 7-19

[77] Pradhan, R. K. and Jena, L. K. (2017). Employee performance at workplace: a conceptual model and empirical validation. Business Perspectives and Research. 5(1), 1-17

[78] Hair, Jr. J. F., G.T.M. Hult, C.M. Ringle and M. Starstedt. (2014). A Premier on Partial Least Squares Structural Equational Modeling (PLS-SEM). California: Sage Publication. Inc

[79] Bollen, K. A. 1989. Structural Equations With Latent Variables. John Wiley \& Sons 